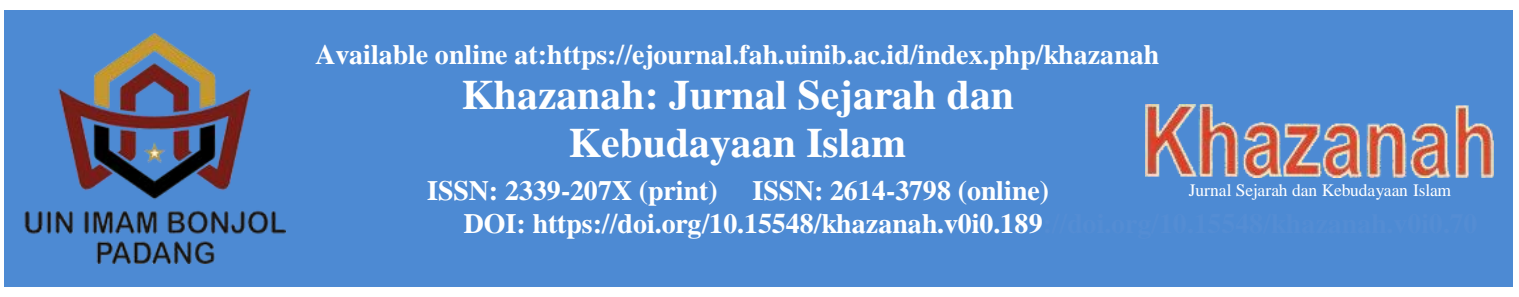

\title{
AMALAN TASAWUF BIDAYATUSSALIKIIN \\ DAN ANEKA MACAM SENJATA (Suntingan Teks dan Kandungan Isi)
}

\author{
Siti Aisyah \\ Fakultas Adab dan Humaniora \\ UIN Imam Bonjol Padang \\ email: sitiaisyah@uinib.c.id
}

\begin{abstract}
This article is about editing the Malay text, entitled bidayatussalikiin. The contents of the text contain pictures of various weapons and swords that were used by the Prophet and his companions and various Sufism people's prayers. The purpose of this paper is to edit the text and contents of the manuscript content of various weapons and various prayers of Sufism practice with a single manuscript research method with the editing method using the diplomatic text edition. Text editing is done on the first and last pages of the manuscript, the first page is the 8th or 4th page of the manuscript and the last page is the 42 nd page or the 21 st page of the manuscript. The contents of the text content of this manuscript are seen on the first page until the seventh page displays various kinds of swords or weapons used by the Prophet and the Prophet's companions, while pages eight to twenty-one are about the benefits of reading certain verses contained in the Qur'an. After that page twenty-second to page fifty-ninth, the contents are about reading prayers for a Sufi in performing various worship and social activities of the community. It can be concluded that this manuscript is a Sufism manuscript because it contains teachings about the practice of Sufism.
\end{abstract}

Keywords: Manuscript, Sufism, Various Kinds of Weapons

\begin{abstract}
Abstrak
Artikel ini menulis tentang suntingan teks naskah Melayu yang judulnya bidayatussalikiin. Isi teksnya terdapat gambar aneka senjata dan pedang yang pernah digunakan oleh Rasulullah dan para sahabat dan ragam doa orang tasawuf. Tujuan tulisan ini melakukan penyuntingan teks dan isi dari kandungan naskah aneka senjata dan ragam doa amalan tasawuf dengan metode penelitian naskah tunggal dengan metode penyuntingan menggunakan menggunakan edisi teks diplomatic. Suntingan teks dilakukan pada halaman pertama dan halaman terakhir dari naskah tersebut, Halaman pertamanya merupakan ke-8 atau lembaran ke 4 dari naskah tersebut dan halaman terakhirnya halaman ke 42 atau lembaran naskah ke 21. Isi dari kandungan teks dari naskah ini dilihat pada halaman pertama sampai halaman ketujuh menampilkan
\end{abstract}


berbagai macam pedang atau senjata yang digunakan Rasulullah dan para sahabat nabi, sedangkan halaman delapan sampai halaman dua puluh satu isinya tentang faedah membaca ayat-ayat tertentu yang terdapat dalam al-Qur'an. Setelah itu halaman ke dua puluh dua sampai halaman kelima puluh sembilan, isinya mengenai bacaan doa bagi seorang sufi dalam melakukan berbagai ibadah dan kegiatan sosial masyarakat. Dapat disimpulkan naskah ini termasuk naskah tasawuf karena isinya memuat ajaran tentang amalan tawasuf.

Kata kunci: Naskah, Tasawuf, Aneka Macam Senjata

\section{PENDAHULUAN}

Naskah kuno merupakan salah satu peninggalan budaya yang penting untuk dilestarikan. Keberadaannya sebagai bukti betapa banyaknya karya para intelektual terdahulu yang sangat berharga untuk dipelajari. Oleh sebab itu perlu sebuah upaya untuk mempertahankan informasi yang terkandung dalam teks naskah tersebut, karena dalamnya terdapat ungkapan ide dan pemikirannya para inteletual dahulu dalam bentuk naskah adat, ilmu keagamaan, sejarah, bahasa Arab. tambo dan jimat dan sebagainya. Semua ide dan pemikiran tersebut ditulis dalam bentuk tulisan tangan pada bahan kertas, daluang, lontar dan sebagainya. Menurut Oman naskah salah satu sumber primer paling otentik yang dapat mendekatkan jarak antara masa lalu dengan masa kini. ${ }^{1}$ Semua informasi dari kandungan naskah tersebut dapat dijadikan sebagai sumber dalam penelitian dan karya tulis para peneliti sekarang dalam mempelajari budaya masa lalu.

Indonesia termasuk negara yang memiliki banyak naskah dari berbagai daerah di Nusantara. Diantara naskah tersebut ada yang sudah tersimpan dengan baik di berbagai perpustakaan dan museum dan ada juga yang terdapat di beberapa surau dan rumah

\footnotetext{
${ }^{1}$ Oman Faturrahman dkk. Filologi dan Islam Indonesia, Kementerian Agama RI, badan Litbang dan Diklat Puslitbang Lektur Keagamaan, Jakarta: 2010, h. 3
}

masyarakat. Naskah yang sudah terdapat di perpustakaan dan museum dapat dikatakan kondisinya sudah diperhatikan sesuai dengan pemeliharaan naskah yang baik, tetapi naskah yang masih disimpan di surau atau rumah pribadi dijaga oleh pemiliknya, belum dapat dijamin secara kondisi sudah terpelihara dengan baik. Belum tentu semua pemilik dan penyimpan naskah pribadi itu memiliki ilmu tentang cara pemiliharaan naskah yang seharusnya. Untuk itu dalam rangka pelestarian naskah kuno tersebut diperlukan penyuluhan dan bimbingan para ahli filolog kepada pemilik naskah yang tersebar ditengah masyarakat.

Objek penelitian ini naskah kuno atau manuskrip yaitu tulisan tangan yang menyimpan berbagai ungkapan pikiran dan perasaan sebagai hasil budaya bangsa masa lampau. ${ }^{2}$ Kata naskah berasal dari bahasa Arab yaitu Naskhatun yang artinya teks. Nama lain dari naskhah ini Manuschrip dan Handschrip. Sedangkan teks menurut isi kandungan yang dimuat dalam naskah tersebut. Jenis naskah juga terdiri dari berbagai macam, ada naskah sastra, kitab, keagamaan, sejarah, bahasa Arab, obat-obatan dan jimat. Tujuan dari keberadaan naskah itu untuk memberikan kebaikan kepada

\footnotetext{
Siti Baroroh Baried, dkk. PengantarTeori Filologi, Yogyakarta: Badan Penelitian dan Publikasi Fakultas (BPPF) Seksi Filologi Fakultas Sastra Universitas Gajah Mada, 1994, h. 55
} 
manusia, tetapi ada pula yang memberi keburukan seperti naskah jimat itu ada yang dapat mendatangkan keburukan pada orang lain. Ada sebagaian orang memiliki naaskah ini untuk mendatangkan keburukan pada manusia. Sedangkan naskah yang diteliti sekarang ini termasuk naskah tasawuf yang di dalamnya memuat tentang keutamaan membaca ayat-ayat al-quran tertentu dalam jumlah tertentu pula.

Meneliti sebuah naskah aktifitas yang terpenting dilakukan adalah kritik teks. Menurut Oman, ada beberapa istilah dalam melakukan aktifitas kritik teks. Autograph merupakan pendekatan filologi yang penting dilakukan sebagai upaya untuk mengembalikan teks sedekat mungkin dengan bentuk pertama yang dihasilkan oleh pengarang. Untuk naskah saksi yangdijadikan sebagai andalan pada sejumlah naskah dikenal dengan nama Witnesses. Sedangkan pisik naskah yang telah mengalami kerusakan dikenal dengan sebutan physical damage. Apabila transmisi itu dilakukan melibatkan tangan-tangan ceroboh disebut dengan istilah fallibility of scribes.dan jika yang membahas naskah tersebut itu tidak paham dengan teks lalu ikut pula campur tangan dalam menambah teks sesuai kepentingan pribadi disebut dengan effects of deliberate interpolation. ${ }^{3}$ Oleh sebab itu untuk melakukan kritik teks dalam sebuah naskah diperlukan wawasan yang sesuai untuk kepentingan naskah, karena kegitan ini tidak bisa dilakukan oleh sembarang orang tanpa memiliki ilmu tentang pernaskahan.

Padang Pariaman merupakan salah satu kabupaten di Sumatera Barat yang termasuk daerah banyak menyimpan naskah. Salah satu nagari di daerah tersebut terdapat suatu daerah bernama Ulakan, dikenal sebagai tempat Syekh Burhanuddin sebagai

$\begin{array}{crrr}3 & \text { Oman } & \text { Fathurraman } & \text { Filologi } \\ \text { Indonesia, h. } & \text { 66-67 } & & \end{array}$

penyebar Islam dengan tarikat Syatariyah. Bentuk penyebaran Islam yang dilakukannya melalui pendidikan surau kepada murid-muridnya, lalu para muridnya pulang kampung halamannya dengan mengajarkan ilmu tersebut di kampungnya. Duski Samad juga menjelaskan dalam tulisannya bahwa murid Syekh Burhanuddin di Ulakan mengambil keahlian dalam berbagai disiplin ilmu, lalu setelah kembali ke kampung mereka juga mendirikan surau juga di kampung. ${ }^{4}$ Selama proses belajar mengajar tersebut para murid ini mencatat ilmu yang disampaikan oleh gurunya dan kemudian dikembangkan pula ilmu tersebut kepada jama'ahnya di tempat para murid ini mengejarkan agama Islam. Oleh sebab itu sampai sekarang naskah yang terdapat di Padang Pariaman cukup banyak tersebar, ada yang terdapat di surau dan ada juga di rumah masyarakat, tetapi belum semuanya terselamatkan dengan baik. Apalagi setelah gempa yang terjadi pada tahun 2009 kemaren, banyak surau tempat penyimpanan naskah yang hancur, sehingga sebagian naskah-naskah tersebut tidak bisa terselamatkan. Naskah yang diteliti sekaarng adalah salah satu naskah di Padang Pariaman yang sempat terselamatkan sebelum peristiwa gempa tersebut. Judul naskahnya bidayatussalikiin. yang isinya tentang aneka pedang masa Rasulullah dan para sahabat dan ragam doa dalam ajaran tasawuf. Permasalahan yang dibahas sekarang tentang suntingan teks dan isi dari kandungan naskah amalan tawaswuf bidayatussalikiin dan aneka macam senjata. Suntingan ini dilakukan untuk mengkaji naskah ini agar dapat dipelajari tentang isi kandungan yang terdapat dalam naskah tersebut. Selain itu meneliti naskah Melayu bidayatussalikiin yang isinya terdapat gambaran tentang aneka senjata dan

4 Duski Samad, Syekh Burhanuddin dan Islamisasi Minangkabau (Syarak Mandaki, Adat Menurun, Jakarta: The Minangkabau Fondation, 2002. 135 
pedang yang pernah digunakan oleh Rasulullah dan para sahabat dan ragam doa orang tasawuf. Tulisan ini melakukan dalam bentuk penyuntingan teks dan isi dari kandungan naskah aneka senjata dan ragam doa amalan tasawuf. Setelah penyuntingan dilakukan penelitian selanjutnya diharapkan dapat membahas dan mengkaji tentang naskah ini secara mendalam tentang kitab bidayatussalikiin dan ragam doa tasawuf.

\section{METODE PENELITIAN}

Berdasarkan ilmu filologi ada beberapa metode yang dilakukan untuk melakukan penelitian naskah. Ada metode intuitif, objektif, gabungan, dan landasan. Masing-masing metode itu dilakukan sesuai dengan tujuan dari penelitian naskah yang dibuat. Naskah yang diteliti sekarang ini jika dilihat dari temanya termasuk naskah tasawuf, tetapi jika ditinjau dari isi kandungan naskahnya termasuk naskah tunggal, karena isi teksnya mengenai bermacam amalan yang harus dilengkapi dengan aneka macam pedang yang harus diketahui oleh seorang tasawuf. Jadi langkah yang dipakai naskah sekarang ini menggunakan metode penelitian naskah tunggal. Metode penyuntingan menggunakan menggunakan edisi teks diplomatic, yaitu menerbitkan suatu naskah seteliti-telitinya tanpa mengadakan perubahan, ${ }^{5}$ karena tekas naskah ini berbahasa Melayu dan kandungan isi teks masih bisa dipahami, jadi belum diperlukan perbaikan dan tafsiran.

\section{PEMBAHASAN}

Naskah yang dijadikan sebagai penelitian ini adalah salah satu naskah yang terdapat di kabupaten Padang Pariaman. Naskah tersebut tersimpan di rumah pribadi Abd, Rahman nagari Gadur, kecamatan Enam Lingkung

${ }^{5}$ Siti Barorah dkk. Pengantar Teori Filologi, S.O. Robson. Prinsip-prinsip Filologi Indonesia, Jakarta: RUL. 1994, h.22.
Kabupaten Padang Pariaman. Ia ini termasuk salah seorang penyimpan naskah semenjak ia belajar agama di Surau Balenggek Lubuk Alung tempat Ia belajar, dan setiap belajar naskah dia membawa naskah yang diberikan gurunya tersebut ke rumahnya, sehingga sampai sekarang memiliki naskah yang tersimpan di rumahnya sekitar sepuluh buah. Khusus naskhah ini tidak diberikan secara lansung oleh gurunya, tetapi ditemukannya tercecer di bawah jendela surau tersebut ketika pergi kesurau tersebut sebelum kejadian gempa di Sumtera Barat tahun 2009. Setelah gempa tersebut semua naskah di surau tersbeut tidak sempat terselamatkan, sehingga tidak ada lagi ditemukan naskah di surau tersebut. Guru dari bapak Abd. Rahman bernama Syekh Ibrahim yang merupakan salah seorang murid dari Syekh Burhanuddin Salah satu naskah yang diteliti sekarang mengenai naskah tentang tasawuf yang berasal dari Surau Balenggek Lubuk Alung Kabupaten Padang Pariaman yang tersimpan di rumah pribadi Abd. Rahman.

Naskah tidak memiliki sampul, hanya lansung halam teks, dan bagian awalnya dimulai dengan gambar berbagai macam pedang atau senjata, Gambarnya dibuat dengan tinta warna merah, dan keterangan gambar dengan tinta warna hitam (Lihat Lampiran). Pada bagian belakangnya juga kelihatan lansung teksnya, tidak ada sampul yang menutupinya dan juga tidak dijilid. Bahkan lembaran kertasnya sudah tidak menyatu lagi, karena benang yang mengikat kurasnya sudah lepas sehingga kertasnya mudah berceceran. Naskah ini termasuk naskah kompilasi, karena di dalamnya terdapat berbagai tema dalam satu naskah, yaitu aneka senjata, ayat fadilah para tasawuf, berbagai doa para tasawuf. Judul naskah di luar tidak ada, yang ada gambar berbagai macam benda dan senjata tajam, tetapi judul di dalam ada ditemukan pada teks awalnya yaitu Kitab Bidayatussakiin dan sampai saat 
ini naskah ini belum ada katalognya dan belum ada ditemukan oleh penulis yang mengkatalogkannya.

Ukuran panjang naskah $16,5 \mathrm{~cm}$ dan lebarnya $10 \mathrm{~cm}$, sedangkan ukuran teks panjangnya $14 \mathrm{~cm}$ dan lebarnya $8 \mathrm{~cm}$. Bentuk naskahnya kecil, kira-kira ukuran kertas kuarto dibagi empat. Jika dihitung lembarannya naskah ini dari ada sebanyak 44 halaman, tetapi tidak sesuai dengan nomor halaman yang tertulis pada naskah tersebut. Pada naskah tersebut nomor awalnya tertulis 32, nomor tersebut terdapat pada halaman kedua bukan halaman pertamanya dan pada halaman terakhir tertulis nomor 59. Cara pemberian nomornya berdasarkan kuarto, yaitu menulis nomor dengan jarak satu halaman, tetapi nomornya meloncat seperti pada halaman 16 tertulis angka 35, kemudian halaman 18 tertulis halaman 40. Selain itu penulisan nomornya berulang, seperti pada halaman 21 tertulis nomor 42 dengan tulisan pensil, kemudian pada halaman 22 juga tertulis nomor 42 dengan tulisan pena. Jumlah baris pada naskah ini tidak seragam, ada jumlahnya sebanyak 23 baris seperti pada halaman 20 jika dihitung dari jumlah lembaran naskahnya. Ada juga baris, 20 baris, ada juga sebanyak 18 baris dan ada juga 17 baris dan bahkan ada yang 16 baris. Namun jumlah baris rata-rata berjumlah antara 16 sampai dengan 18 baris.

Bentuk teksnya berbentuk prosa, yaitu kumpulan macam senjata Rasul dan para sahabat, faedah dari bacaan surat-surat tertentu dalam al-Qur'an dan doa-doa tasawuf. Bentuk tulisannya kecil, menggunakan aksara Arab dan berbahasa Melayu. Bahan kertasnya menggunakan kertas Eropa, karena pada kertas itu terdapat tanda air dengan gambar singa dalam lingkaran atau propatua, terdapat disudut kertas. Berdasarkan informasi dari Monumenta Charte Papyraceae Historiam Ilustrantia en collection works and illustrating the History of Paper General, usia kertas dengan watermak singa dalam lingkaran ada sekitar 300250 tahun yang lalu. ${ }^{6}$ Warna tintanya hitam dan merah tetapi tidak ada iluminasi, sedangkan ilustrasinya ada, seperti pada halaman pertama sampai halaman tujuh. Kolofonnya ada, terdapat pada halaman 42 (ditulis dengan pensil) tetapi tidak ditemukan tanggal penulisannya, hanya nama penulisnya yaitu Haji Muhammad Ja'far. Kondisi naskah cukup baik, tetapi jahitan benangnya sudah lepas, sehingga lembaran kertasnya terlepas. Di antara pinggiran kertas sudah mulai rapuh dan sudah rusak terutama bagian tujuh lembar yang terakhir

Petikan awal teks isinya: Keluar dalam kitab bidayatussalikiin. Artinya barang siapa bercampur akan orang yang baharu belajar ilmu fiqih pada masa ini niscaya maka atas tabiatnya itu berbantah pada bicara masalah ilmu ini dan sejalan akan perkataan orang dan susah atas diam karena menjatuhkan kepadanya oleh orang alim yang jahat bahwa yang demikian itu yaitu.... Sedangkan petikan akhir teks yaitu: Barangsiapa melihat mayat jikalau tiada membaca doa ini maka dibinasakan Allah Taala amalnya empat tahun. Inilah doanya yang dibaca: Allahummagfirly, walihabdika min 'azabilkubur, wa'azabinnar, wassuahi munkaru, wanakiirun maau. Subhana man ta'uzzuna bilqudrati, walbaqaai, waqahaaril'ibaadi bilmauti, wal fanai kullu.

\section{Suntingan Teks}

Bagian awal naskah ini yang terdapat teksnya pada naskah ini terdapat pada halaman ke-8 atau lembaran ke 4 dari naskah ini. Suntingan teks yang dilakukan adalah dengan menggunakan metode suntingan diplomatik yaitu melakukan

\footnotetext{
${ }^{6}$ Edwar Heawood, Monumenta Charte Papyraceae Historiam Ilustrantia en collection works and illustrating the History of Paper General, Editor : E.J Labarre I Watermarka Mainly of the 17 th and $18^{\text {th }}$ Centuries, Hilpersium (Holland):The Paper Publications Society , MCML
} 
penyuntingan dengan tidak merubah atau menafsirkan dari kalimat tersebut. Jadi teks naskah ini berbahasa Arab Melayu dijadikan dalam bentuk latin tanpa merubah bacaan dan tanpa melakukan penafsiran dari teks tersebut. Sedangkan teks akhir yang dilakukan penyuntingan ini terdapat pada halaman terakhir naskah yaitu halaman 42 atau lembaran 21 dari naskah tersebut

\section{a. Teks Awal}

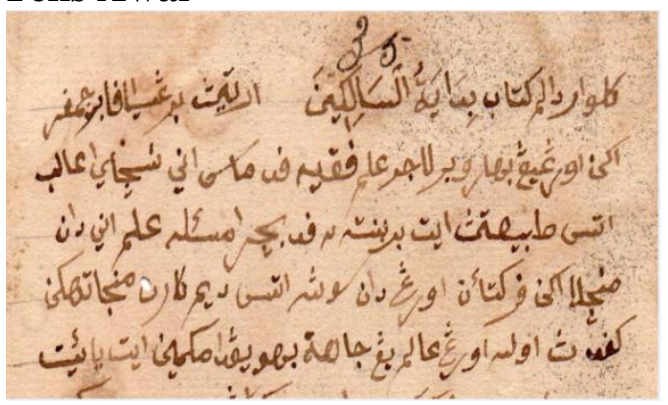

Foto naskah halaman ke-8 atau lembaran 04 dari naskah (Foto milik Penulis)

Translet teks:

keluar dalam kitab bidayatussalikiin. artinya barang siapa bercampur

akan orang yang baharu belajar ilmu fiqih pada masa ini niscaya [ ain, alif. Lam, ba]

atas tabiatnya itu berbantah pada bicara masalah ilmu ini dan

sejalan akan perkataan orang dan susah atas diam karena menjatuhkan kepadanya oleh orang alim yang jahat bahwa yang demikian itu yaitu...

b. Teks Akhir

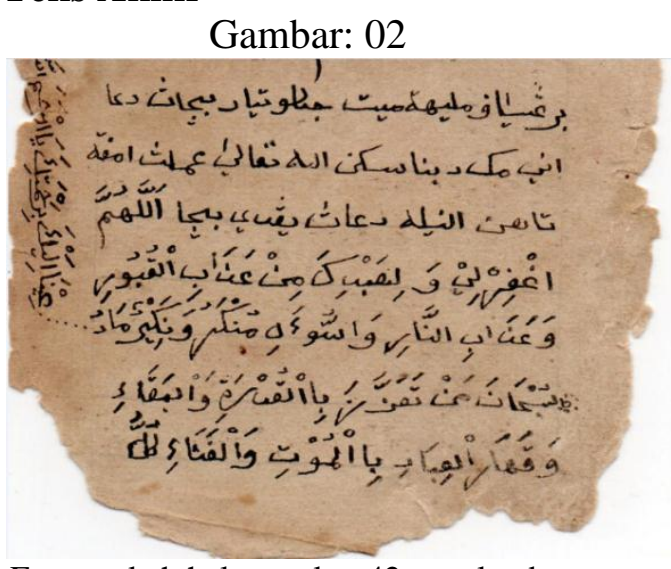

Foto naskah halaman ke- 42 atau lembaran

Translet teks: barang siapa melihat mayat jikalau tiada membaca doa

ini maka dibinasakan Allah Taala amalnya empat

tahun. Inilah doanya yang dibaca: Allahummag

firly, walihabdika min 'azabilkubur, wa'azabinnar, wassuahi munkaru, wanakiirun maau.

subhana man ta'uzzuna bilqudrati, walbaqaai,

waqahaaril'ibaadi bilmauti, wal fanai kullu.

\section{Isi kandungan Naskah}

Isi dari kandungan naskah ini membahas tentang amalan yang harus dilaksanakan oleh para sufi yang hendak mendalami ilmu tasawuf. Dari halaman pertama sampai halaman ketujuh isinya memuat tentang berbagai macam pedang atau senjata yang digunakan Rasulullah dan para sahabat nabi.

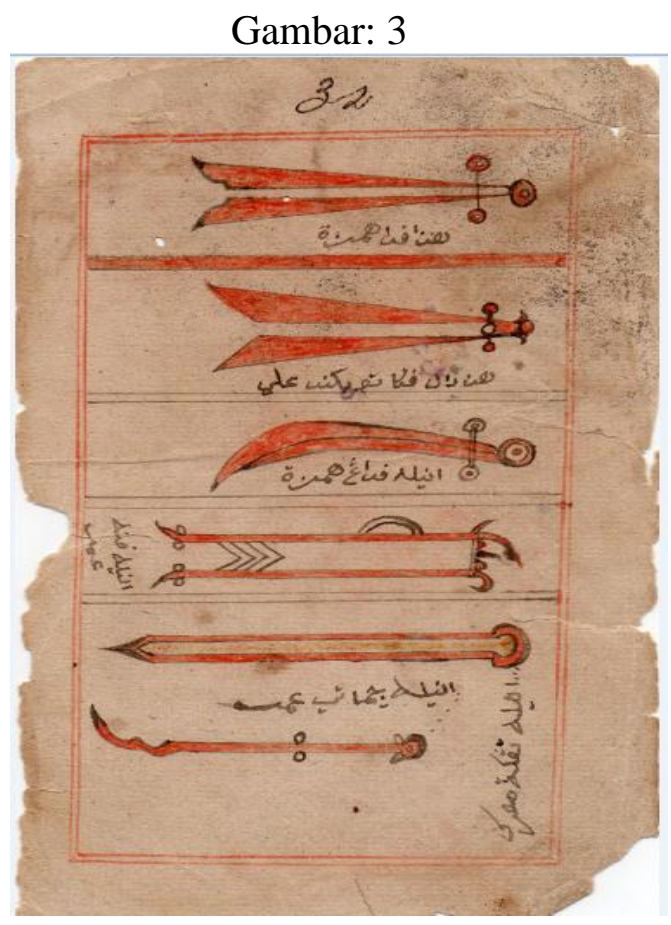

Salah satu isi naskah bergambar aneka bentuk senjata tajam terdapat pada naskah halaman ke-2, (Foto milik penulis)

Kemudian pada halaman delapan sampai halaman dua puluh satu tentang 
faedah membaca ayat-ayat tertentu yang terdapat dalam al-Qur'an. Seperti yang terdapat pada halaman kedelapan paragraf terakhir tulisannya:

\section{barangsiapa membaca}

qulhuwallahu ahad lima puluh kali terangkatlah kejahatannya 50

ribu dan tersurat 50

ribu kebajikan.

Selanjutnya pada halaman ke dua puluh dua sampai halaman kelima puluh sembilan, isi kandungan naskahnya mengenai bacaan doa bagi seorang sufi dalam melakukan berbagai ibadah dan kegiatan sosial masyarakat sebagaiman yang terdapat pada 35 dari naskah tersebut. Teks dalam naskah tersebut umumnya menuliskan tentang do'a, seperti do'a menghadiri jamuan makan, menyembelih binatang, dan pelaksanaan sembahyang qada, sembahyang malam, termasuk juga doa ketika melihat mayat. Gambar naskah tersebut terdapat pada halaman ke-1 sampai dengan halaman ke-7 yang isinya tentang beberapa bentuk senjata tajam berupa kapak, pedang dan panah. Pada halaman ke-5 sampai ke halamake-6 menampilkaan bentuk gambar senjata tajamdalam bentuk kipas Rasulullah, jimat hamzah dan aksesoris lainnya. Diakhir naskah ini dijelaskan bahw semua gambar tersebut apabila sudah dilihat oleh para sufi, mereka dapat terhindar dari jin dan setan yang menggoda manusia.

\section{KESIMPULAN}

Naskah ini memuat pembahasan amalan yang harus dilakukan oleh orang tasawuf. Dalam naskhah tersebut setiap orang tasawuf diperkenalkan berbagai sejata yang digunakan oleh Nabi Muhammad dan keluarga serta kerabatnya. Apabila mereka sudah melihat senjata itu maka tidak ada lagi yang bisa mengganggunya, dan malah tidak berani lagi menganggunya. Teks dari naskah ini tulisannya mengenai amalan ayat yang khusus dibaca dan diamalkan oleh pengamal tasawuf. Selain itu di dalamnya juga terdapat beberapa amalan doa yang harus dilakukan sebagai orang tasawuf. Dua hal pokok yang terlihat pada isi naskah ini menampilkan berbagai macam pedang dan teks amalan doa dalam bentuk ilmu kebatinan yang perlu diamalkan oleh seorang tasawuf,. Ditinjau dari kandungan isi naskah dapat dikategori termasuk naskah azimat, karena di dalamnya menuliskan berbagai amalan doa tentang anjuran membaca ayat-ayat tertentu dan doa yang harus dibaca seorang tasawuf serta pemberitahuan keuntungan bagi seorang tasawuf jika melihat gambar aneka macam senjata. 
32 Amalan Tasawuf Bidayatussalikiin...

\section{DAFTAR KEPUSTAKAAN}

Baried, Siti Baroroh dkk. (1994) PengantarTeori Filologi, Yogyakarta: Badan Penelitian dan Publikasi Fakultas (BPPF) Seksi Filologi Fakultas Sastra Universitas Gajah Mada,

Faturrahman, Oman dkk. (2010) Filologi dan Islam Indonesia, Jakarta: Kementerian Agama RI, badan Litbang dan Diklat Puslitbang Lektur Keagamaan

Heawood, Edwar (T.Th) Monumenta Charte Papyraceae Historiam Ilustrantia en collection works and illustrating the History of Paper General, Editor : E.J Labarre I Watermarka Mainly of the $17^{\text {th }}$ and $18^{\text {th }}$ Centuries, Hilpersium (Holland):The Paper Publications Society, MCML

Robson. S.O. (1994) Prinsip-Prinsip Filologi Indonesia, Jakarta: RUL

Samad, Duski (2002) Syekh Burhanuddin dan Islamisasi Minangkabau (Syarak Mandaki, Adat Menurun, Jakarta: The Minangkabau Fondation 